\title{
Seismogenic faulting in the Meruoca granite, NE Brazil, consistent with a local weak fracture zone
}

\author{
ANA CATARINA A. MOURA ${ }^{1}$, PAULO H.S. DE OLIVEIRA ${ }^{2}$, JOAQUIM M. FERREIRA ${ }^{2}$, \\ FRANCISCO H.R. BEZERRA ${ }^{2}$, REINHARDT A. FUCK ${ }^{1}$ AND ADERSON F. DO NASCIMENTO ${ }^{2}$ \\ ${ }^{1}$ Universidade de Brasília, Campus Universitário Darcy Ribeiro, \\ Instituto de Geociências, Asa Norte, 70910-900 Brasília, DF, Brasil \\ ${ }^{2}$ Departamento de Geologia, Universidade Federal do Rio Grande do Norte, \\ Campus Universitário, 59072-970 Natal, RN, Brasil
}

Manuscript received on January 25, 2013; accepted for publication on May 5, 2014

\begin{abstract}
A sequence of earthquakes occurred in 2008 in the Meruoca granitic pluton, located in the northwestern part of the Borborema Province, NE Brazil. A seismological study defined the seismic activity occurring along the seismically-defined Riacho Fundo fault, a $081^{\circ}$ striking, $8 \mathrm{~km}$ deep structure. The objective of this study was to analyze the correlation between this seismic activity and geological structures in the Meruoca granite. We carried out geological mapping in the epicentral area, analyzed the mineralogy of fault rocks, and compared the seismically-defined Riacho Fundo fault with geological data. We concluded that the seismically-defined fault coincides with $\sim \mathrm{E}-\mathrm{W}$-striking faults observed at outcrop scale and a swarm of Mesozoic basalt dikes. We propose that seismicity reactivated brittle structures in the Meruoca granite. Our study highlights the importance of geological mapping and mineralogical analysis in order to establish the relationships between geological structures and seismicity at a given area.
\end{abstract}

Key words: Meruoca pluton, Riacho Fundo fault, seismological data, Transbrasiliano Lineament.

\section{INTRODUCTION}

The mechanisms of seismicity in stable continental interiors are not as well understood as those of plate boundaries. One of the most common explanations for earthquakes in stable continental regions is the reactivation of preexisting zones of weakness (Sykes 1978, Scholz 1998). Several studies show that structural reactivation plays an important role in the seismogenic faulting, but others indicate that reactivation is not the main cause and suggest other explanations such as thermal effect (e.g., Sandiford

Correspondence to: Ana Catarina de Almeida Moura

E-mail: anacatarina@unb.br and Egholm 2008). Therefore, the understanding of the relationship between seismicity and major structures in stable continental interiors is still pending in many areas, especially because of the qualitative concept of "weakness zone".

The relation between seismicity and preexisting structures is complex in the Borborema Province, northeast Brazil, the most seismically active area in the South American stable continental interior (South American platform). Seismically-defined faults either reactivate or cut across preexisting structures (Bezerra et al. 2011). For example, Ferreira et al. (2008) and Lopes et al. (2010) 
concluded that the seismicity in the Caruaru and Belo Jardim areas reactivated the Pernambuco lineament, a continental-scale ductile shear zone (Fig. 1), established at the end of the Neoproterozoic
Brasiliano orogeny (Brito Neves et al. 2000). By contrast, seismicity in the Palhano area cuts across the NE-trending Precambrian fabric (Ferreira et al. 1998, Bezerra et al. 2011).
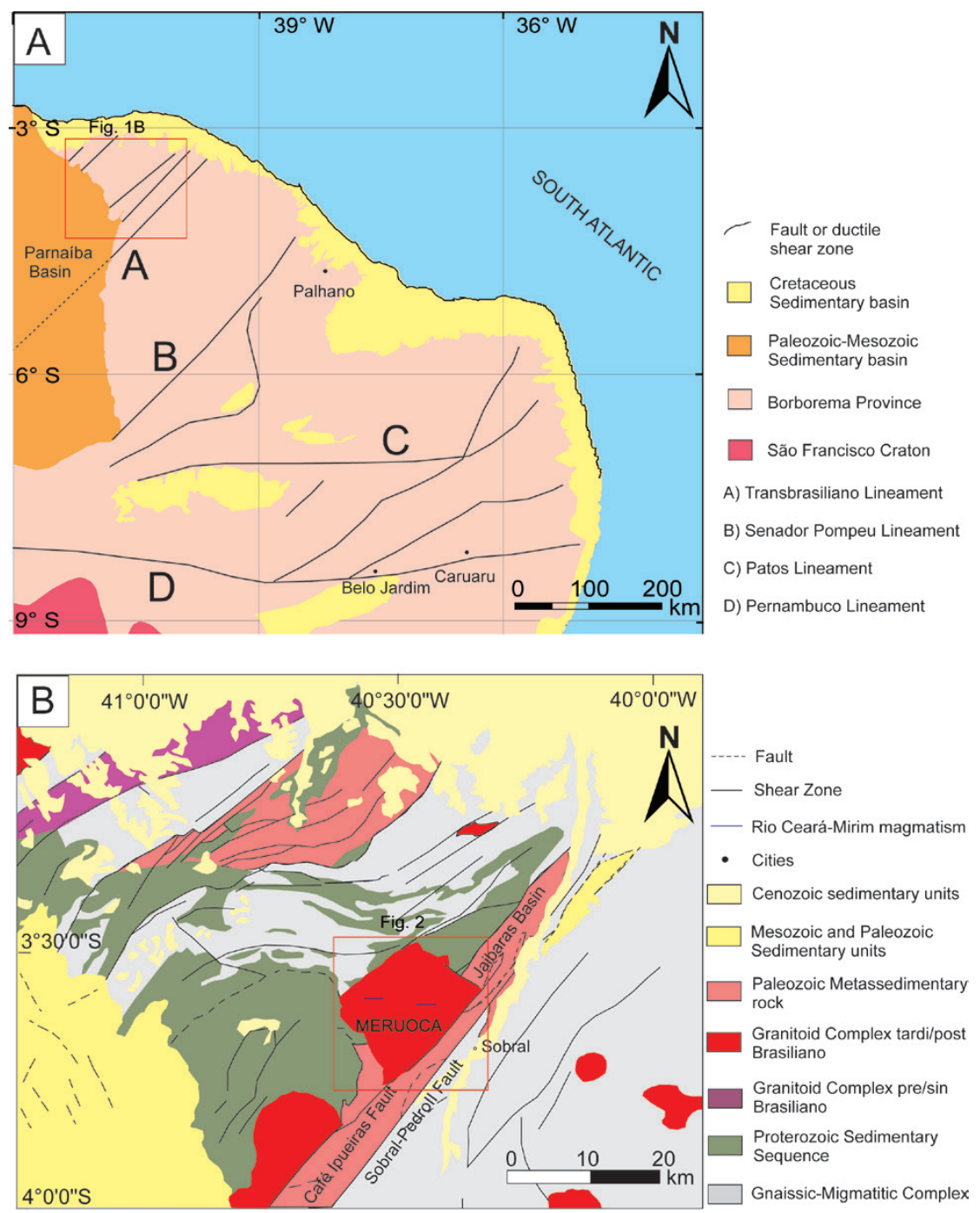

Figure 1 - A) Borborema Province with structural compartments. Simplified from Bizzi et al. (2003). B) Médio Coreaú Domain with lithological and structural compartments. Red square represent area of Figure 2. After: CPRM 2003.

The present study investigates the relationship between the seismically-defined Riacho Fundo fault (Oliveira et al. 2010) and faults identified at outcrop scale in the Meruoca granite area (Fig. 1b). An earthquake sequence struck this area in 2008, with a maximum event magnitude of $3.8 \mathrm{~m}_{\mathrm{b}}$. The area is affected by shear zone of the Transbrasiliano lineament, a ca. $6,000 \mathrm{~km}$ long shear zone reactivated several times in the Phanerozoic. The relationship or lack of one between the seismicity and those structures is not known. We present a detailed structural map of the area, which includes 
faults and a swarm of basalt dikes. In addition, we present the geometry, kinematics, mineralogy, and chronology of the brittle structures. We conclude that the seismically-defined Riacho Fundo fault reactivates basalt dikes and faults identified at outcrop scale along the Boqueirão valley (Fig. 2), an E-W-trending structure that splits the Meruoca granite. The present study highlights the importance of detailed structural mapping of epicentral zones in stable continental region.

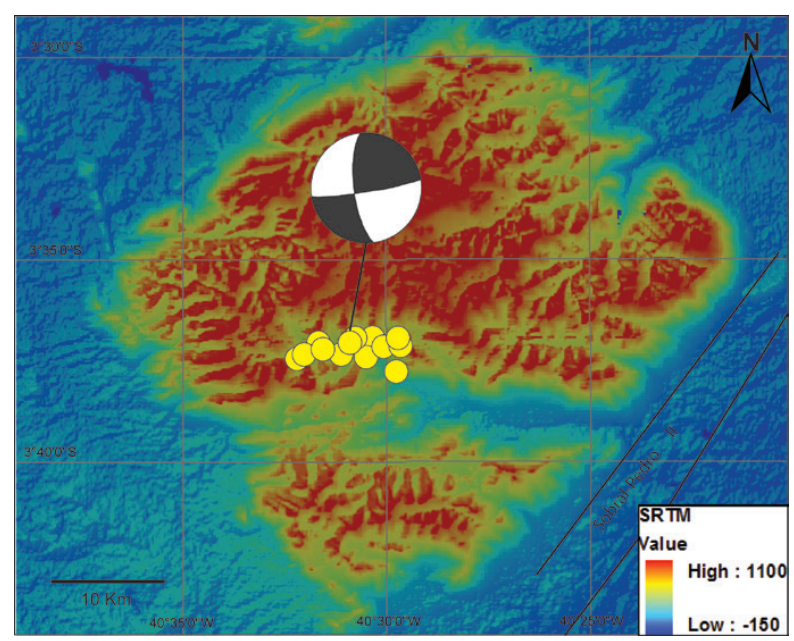

Figure 2 - SRTM map of hypocenter location (yellow circles) showing focal mechanism and Transbrasiliano lineament. (Modified from Oliveira et al. 2010).

\section{SEISMOTECTONIC SETTING}

TeCtonic FeAtures of the Borborema Province

The Borborema Province is a complex mosaiclike folded region located in northeastern Brazil. It comprises basement gneiss and migmatite complexes, deformed and metamorphosed supracrustal sequences, a number of granite plutons, and four major shear zones: Transbrasiliano, Senador Pompeu, Patos, and Pernambuco lineaments (Fig. 1). The whole province was deformed during the Brasiliano-Pan African orogeny at 750-540 Ma (Almeida et al. 1981, Brito Neves et al. 2000).
The study area is located in the northwestern of part of the Ceará State, Ne Brazil, within the Médio Coreaú Domain which is bounded to the west by the Parnaiba basin and to the east by the Transbrasiliano lineament (Fig. 1). It is structurally defined by horsts and graben striking northeast. Four ductile deformational phases from the Paleoproterozoic to the Neoproterozoic affect this domain. The Meruoca pluton is dated $523 \pm 9 \mathrm{Ma}$ (U-Pb zircon - SHRIMP, Archanjo et al. 2009), it lacks ductile deformation, and represents postorogenic plutonism (Santos et al. 2008).

The seismically-defined Riacho Fundo fault occurs in the Meruoca granite (Oliveira et al. 2010). The Meruoca granite is comprised mainly by granite, quartz syenite, and alkali-feldspar granite. Large areas characterized by turbid brick-red feldspar and located in the center-south part of the pluton indicate that the Meruoca was a high-level intrusion that experienced pervasive, late hydrothermal alteration (Sial et al. 1981). Dark vein filling composed of oxidized hematite and magnetite in brecciated granite also occurs in the central-south part of the pluton. These veins were described as an association typical of Iron Oxide-Copper-Gold deposits (IOCG) (Parente et al. 2011). Gabbroic rocks also occur in the center of the Meruoca pluton (Gonçalves unpublished data), as well as in its NW corner (Pedrosa et al. 2011).

The Jaibaras Basin is located to the east of the Meruoca pluton. The basin filling is comprised of continental immature siliciclastic deposits and volcanoclastic rocks of early Paleozoic age (Santos et al. 2008). The genesis of the basin used to be considered as a molasse-type basin, but recent studies show that its generation is associated with the reactivation of the Transbrasiliano lineament in a rift stage (Oliveira 2000, Oliveira and Mohriak 2003).

The most important Mesozoic magmatic event in the area was the Rio Ceará Mirim Magmatism (Gomes et al. 1981). It yielded K-Ar ages that peak 
at $\sim 130 \mathrm{Ma}$, which is associated with the breakup of Pangea. It is composed of tholeiitic diabase dikes, oriented predominantly in the $\mathrm{E}-\mathrm{W}$ direction. Recent ${ }^{40} \mathrm{Ar} /{ }^{39} \mathrm{Ar}$ dates identified an age plateau at $132.2 \pm 1 \mathrm{Ma}$ that represents one of the phases of this magmatic event (Souza et al. 2003).

\section{SEISMICITY OF THE BORBOREMA PROVINCE}

The Borborema Province is one of the most important seismic areas in the stable continental region of South America. Historical data suggest the occurrence of earthquakes since the nineteenth century. Seismographs have monitored the region since 1965 showing that earthquakes with magnitudes of $5 \mathrm{~m}_{\mathrm{b}}$ occur on average every 5 years with intensities of up to VII Mercalli Modified (Ferreira and Assumpção 1983). These events are felt over several hundred kilometers away from the epicenter (Ferreira et al. 1998). Active faults in Borborema Province are usually strike-slip and generate events of up to $5.2 \mathrm{~m}_{\mathrm{b}}$ Seismicity is concentrated in the upper crust down to a depth of $12 \mathrm{~km}$ (Ferreira et al. 1998, 2008).

Stress fields studies using focal mechanisms, borehole breakouts, fault slip data, and inelastic strain recovery measurements, indicate that the region is under a strike-slip regime. This stress field comprises a sub-horizontal compressive stress roughly parallel to the direction of absolute plate motion (Assumpção 1992). On a local scale, the present-day stress field exhibits E-W-oriented compression and $\mathrm{N}-\mathrm{S}$-oriented extension. However, focal mechanisms indicate that $\mathrm{S}_{\mathrm{Hmax}}$ (maximum horizontal compression) rotates $\sim 45^{\circ}$ from $\mathrm{E}-\mathrm{W}$ to NW-SE in the Potiguar Basin and along the continental margin of the state of Ceará (Assumpção 1992, Ferreira et al. 1998, 2008, Bezerra et al. 2007, 2011). This local stress field would be influenced mainly by lateral density variations across continental/oceanic boundary, as well as flexural stresses (Assumpção 1992, Ferreira et al. 1998).

\section{MATERIALS AND METHODS}

We combined the results of the seismic survey carried out by Oliveira et al. (2010) with structural mapping, and laboratory analysis of fault mineralogy. The laboratory techniques included thin section and scanning electron microscopy (SEM).

An earthquake of magnitude $3.8 \mathrm{~m}_{\mathrm{b}}$ occurred in the Sobral area on May 21, 2008. A local network was installed in the epicentral area from June 6 to September 24, 2008. In this study we considered 581 events that were recorded by at least three stations (Oliveira et al. 2010). These authors used the HYPO 71 software and chose 24 events that had the best hypocentral precision to determine the seismicallydefined fault plane (Fig. 2). The events represent a 1-8 $\mathrm{km}$ fault, with maximum rms time error of $0.03 \mathrm{~s}$, maximum horizontal error (erh) of $0.1 \mathrm{~km}$, maximum vertical error of $0.2 \mathrm{~km}$. The structural mapping was carried out in April and November 2010 and the collected data were used to plot paleostress diagrams. Rake determination was particularly difficult due to geometry of some outcrops.

Thin sections were prepared in order to describe the structural and mineralogical characteristics of the faulting. In addition, filling of the outcrop scale faults was analyzed by SEM (model SSX - 550, SHIMADZU) and Energy Dispersive Spectrometry (EDS) at the Centro de Tecnologia do Gás (CTGas-RN) and on a microprobe (JEOL Superprobe JXA-8230) at the University of Brasília.

\section{RESULTS}

\section{SEISMICALLY-DEFINED FAULT}

Oliveira et al. (2010) determined an alignment of hypocenters using the least squares method to adjust the more likely fault plane and named it the Riacho Fundo fault. The seismically-defined fault is located in the center-south part of the granite. The hypocentral data indicate that the fault is $6 \mathrm{~km}$ long, 1 to $8 \mathrm{~km}$ deep, strikes 081 , and dips $\sim 85^{\circ}$ to the southeast. Oliveira et al. (2010) divided the fault into 
three segments and calculated a focal mechanism for each one. Each focal mechanism corresponds to a variation in depth: shallow $(1.1-3.4 \mathrm{~km})$, intermediate (3.4-5.7km), and deep (5.7-7.8km) earthquakes. The nodal planes of these focal mechanisms agree with the trend of hypocenters. In our study, we present a composite single focal mechanism for the whole fault for the sake of clarity. The results of the seismological study are presented in Figure 2. The epicenters reveal an E-W-striking, strike-slip seismically-defined fault (Riacho Fundo fault) $6 \mathrm{~km}$ long.

\section{EVIDENCE OF BRITTLE DEFoRMATION FROM FIELD DATA}

The Meruoca granite is a post-orogenic intrusion with no evidence of ductile deformation. The granite cuts across the Precambrian basement, which was deformed during the Brasiliano orogeny. It also cuts across the Jaibaras Basin and represents the last magmatic event of the area. The digital elevation model shows a square-shaped pluton, 800 to 1,000 $\mathrm{m}$ high, whose boundaries are oriented SW-NE and SE-NW. The southern part of the pluton is marked by a $10 \mathrm{~km}$ long and $3 \mathrm{~km}$ wide valley, called Boqueirão Valley, that presents steep walls and triangular facets, which are typical of recent tectonic activity. The seismically-defined Riacho Fundo fault occurs at the northern scarp of this valley.

Fault rocks at the outcrop scale are mainly cataclasites and fault gouges. Cataclasites form coherent narrow zones 2-20 cm wide. Clast fragments from the Meruoca Granite vary in size from a few centimeters to as much as $15-20 \mathrm{~cm}$, whereas the percentage of a dark matrix varies significantly and could reach $90 \%$. We observed several generations of cataclasites, i.e., fragments of cataclasites inside a younger cataclasite. Fault gouge form unlithified material that occur in a few outcrops and were formed at a shallow level of faulting. Gouge zones width usually vary from 5-15 cm., however, the large faults in the study area occur below rivers associated with Quaternary alluvium and could not be observed directly.
We grouped the faults identified at the outcrop scale into two different paleostress fields. The NEstriking structures presents a sub-horizontal NEtrending $\sigma 1$ and a sub-horizontal NW-trending $\sigma 3$. The E-W and NW faults present a NW-trending $\sigma 1$ and a NE-trending $\sigma 3$ (Fig. 3 and 4). Cross cutting relationships indicate that the former stress field is the first while the latter represents the most recent brittle event (Fig. 3).
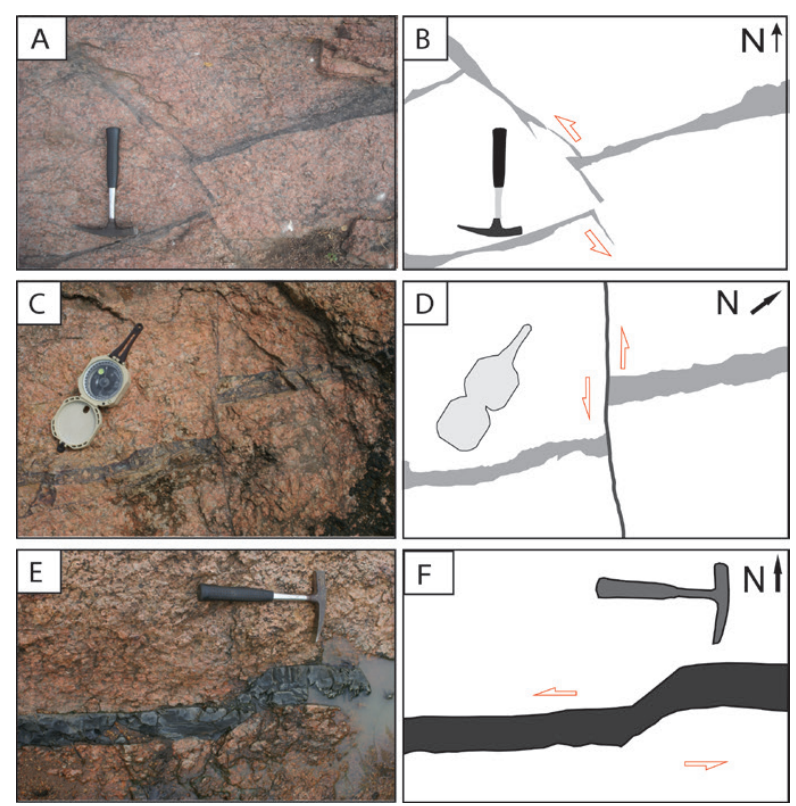

Figure 3 - Photos and sketches of faults in the Boqueirão valley. A, B and C, D represent NE faults intersected by NW faults, both filled with opaque iron oxide material. E, F show an E-W-trending basalt dike.

\section{Brittle Deformation at A Microscopic SCALE}

In the thin sections studied we identified three fault planes: faults filled with opaque material, faults filled with quartz, and faults without filling material. In samples from the NE and NW-trending faults we identified some small veins (up to $2 \mathrm{~mm}$ wide), whose crystals were orthogonal to the main fault plane. Two types of boundaries from the rock to the fault plane occur. The first one is abrupt and exhibits a sharp contact between K-feldspar grains and the opaque material filling the fault plane. The second is 


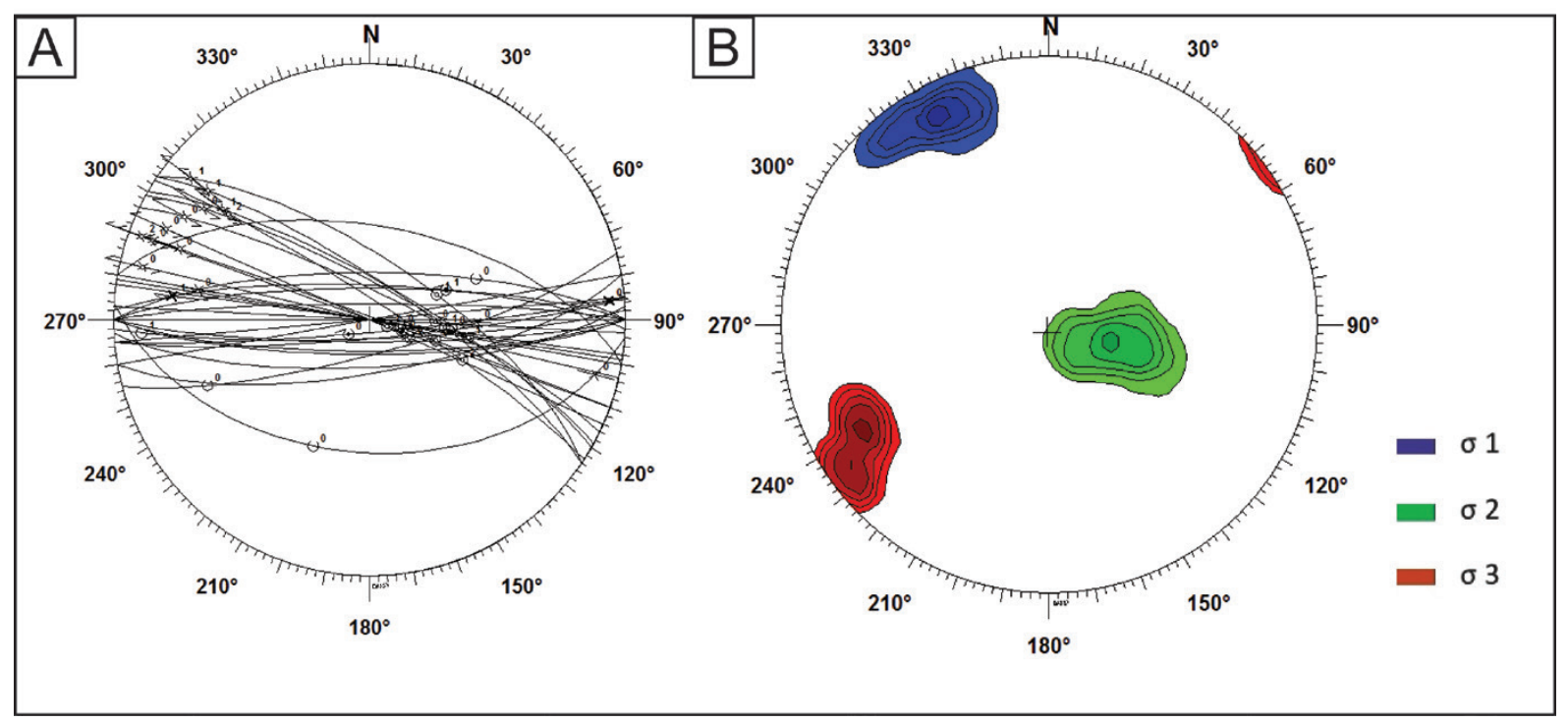

Figure 4 - Paleostress diagrams for the most frequent faults, E-W and NW-SE faults.

a gradational transition with grains of K-feldspar and quartz decreasing in numbers and size from the wall rocks to the fault core (Fig. 5A, B). The main texture found in the thin section of the NW and NE faults is of cataclasite, which shows angular rock fragments, mainly composed of quartz and embedded in a matrix of iron oxide. Most of the quartz in wall rock and angular fragments in the fault presents undulated extinction associated with faulting. The wall fragments in the fault infilling range from $\sim 5$ $\mathrm{mm}$ to less than $0.1 \mathrm{~mm}$. Some of the NW faults in Boqueirão valley present no filling. The $\mathrm{N}-\mathrm{S}$ faults present quartz exudation $(>1 \mathrm{~mm})$ and small opaque grains. The quartz grains present recrystallization and undulated extinction and rare thin $(>0.05 \mathrm{~mm})$ randomly disposed iron-oxide veins.

The SEM method was used to identify high Fe content in the veins in a semi-quantitative analysis. In addition, a microprobe study was performed in order to identify the mineralogy of the veins. We were able to verify that the opaque matrix and black veins filling the NW and NE fault breccias were hematite in four thin sections. We analyzed the fault matrix in some targets and in others there was some contamination due to very small grains of quartz dispersed in it. The images from the backscattering (BSE) show a gradational transition from wall rock to the breccia phase (Fig. 5C, D).

\section{DISCUSSION AND CONCLUSION}

The seismicity of the Meruoca granite is similar to that associated with veins and dikes, such as in the Samambaia fault, described by Bezerra et al. (2011). The NNW-SSE paleo sigmal reactivated WNWESE structures. These structures were originated by the younger brittle event recognized in the study area, also considering the crosscut relationship between NE and NW structures and the absence of filling in some NW-trending faults. This younger event is consistent with the Neotectonic stress field. In the Meruoca Granite, the recognized hardened cataclasites and iron oxide cement indicate older and deeper generated fault traces (rocks) that are not associated to measured earthquakes. However, the seismological data indicate that the focal mechanism from the recent earthquakes coincides with the paleostress field that creates and is prone to reactivating the WNW-ESE and NW structures. Although these faults are not recent, the faults and the swarm of basalt dikes are optimally oriented 

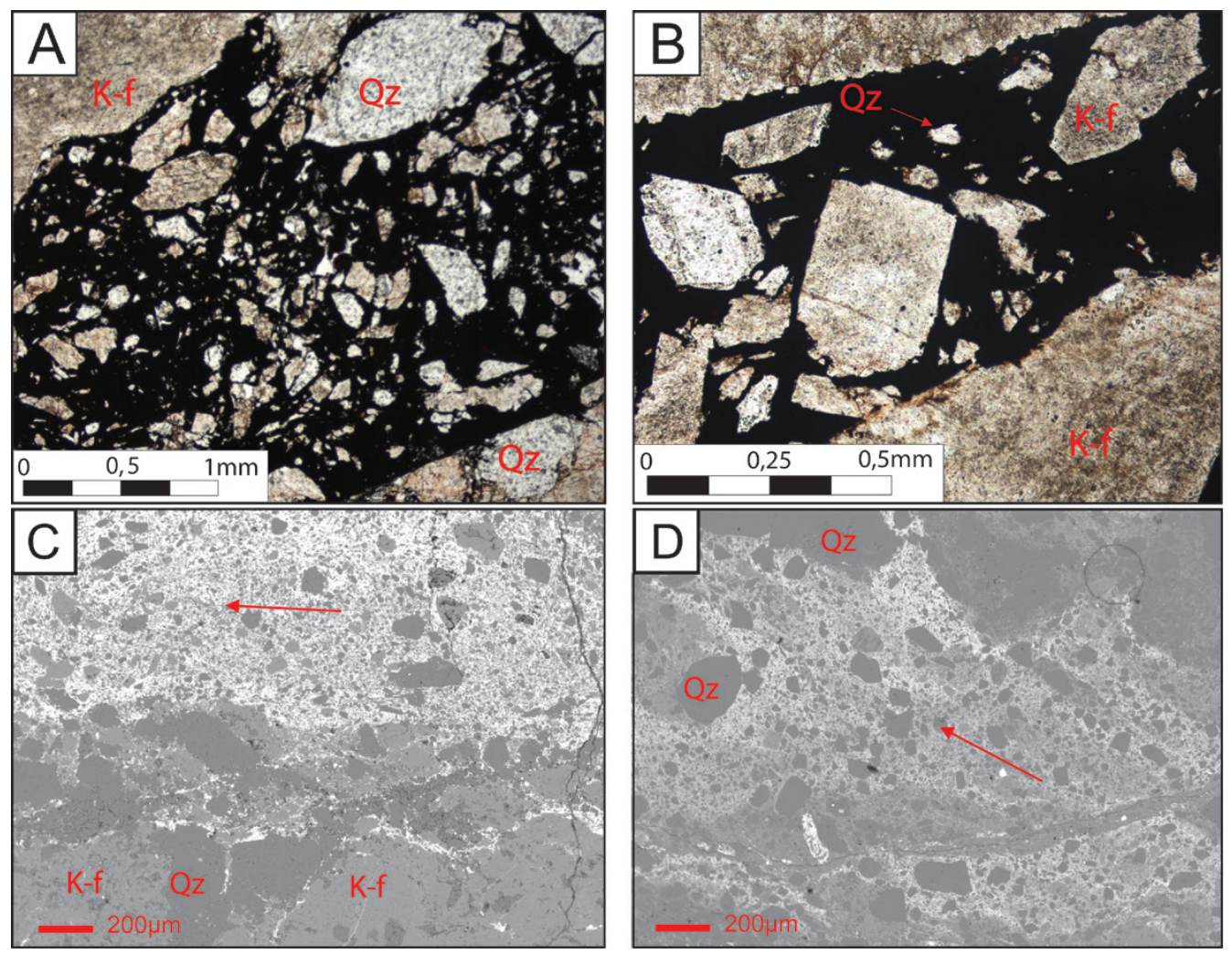

Figure 5 - A and B photos of thin sections showing sharp contact between the rock and the vein (Fe oxide) and angular clasts of quartz and feldspar of NW faults - N//. K-f - K-feldspar, Qz- quartz. C and D texture of thin sections in microprobe BSE photos. Red arrows indicate direction of flow. K-f-K-feldspar, Qz- quartz.

to reactivation by the present-day stress field. These faults and the swarm of basalt dikes are the preexisting zone of weakness on a local scale.

New data on the Borborema Province are now available to contribute towards the understanding of the behavior of the seismically active faults in the region. Unlike the Pernambuco lineament, where earthquakes are due to reactivation of the main shear zone (Ferreira et al. 2008), the Transbrasiliano lineament does not present a direct relationship with the recent earthquakes in the Meruoca granite. In addition, unlike the Palhano and Augusto Severo cases, where the seismicity is related to faults that cut across preexisting structures, the Meruoca seismicity is related to the northern scarp of the Boqueirão valley, a remarkable $10 \mathrm{~km}$ long and $3 \mathrm{~km}$ wide structure located center-south of the granite.
We conclude that the seismically-defined Riacho Fundo fault is not directly linked to a nearby continental-scale shear zone reactivated in the Paleozoic, the Transbrasiliano lineament. The Riacho Fundo fault, however, coincides with E-Wtrending faults and Jurassic-Cretaceous basalt dikes that cut across the Meruoca granite. These structures occur along the Boqueirão valley, which is also an E-W-trending structure that exhibits steep scarps and disrupts the granite topography. In addition, the Boqueirão valley, which is also an E-W-trending structure, was formed and oriented in that manner due to the existence of the Riacho Fundo fault. We conclude that the Riacho Fundo seismogenic fault is a weak preexisting local structure, but that it is not a case of reactivation of a major shear zone similar to the Pernambuco lineament, as expected. 


\section{ACKNOWLEDGMENTS}

We thank Marcelo Assumpção and two anonymous reviewers for their careful review, which significantly improved our paper. The field work was supported by grants provided by both Instituto Nacional de Ciência e Tecnologia em Estudos Tectônicos (INCT-ET 573.713/2008-1) and Petrobras project Lineamento Transbrasiliano: origem, evolução e influência na sedimentação de bacias fanerozóicas (0050.023165.06.4). ACA Moura thanks Brasilia University, Conselho Nacional de Desenvolvimento Científico e Tecnológico (CNPq) for the scholarship and Aureliano Nóbrega for the field trip and discussions. The authors thank the Microprobe Laboratory of the Brasília University.

\section{RESUMO}

Em 2008 uma série de tremores ocorreu no Granito Meruoca, localizado na porção noroeste da Província Borborema. A atividade sísmica foi identificada ao longo da falha Riacho Fundo com direção $081^{\circ} \mathrm{Az}$ e profundidade de 8 quilômetros. O objetivo do estudo foi analisar a correlação entre a atividade sísmica e as estruturas encontradas no Granito Meruoca. Foi realizado um mapeamento geológico na área epicentral, com análise da mineralogia das rochas de falha e comparação com os dados sismológicos da falha Riacho Fundo. Chegamos à conclusão que a falha sismogênica coincide com as falhas de direção E-W encontradas em escala de afloramento e com o enxame de diques basálticos mezosóicos. Nós propomos que as estruturas frágeis do granito Meruoca foram reativadas pela sismicidade. Nosso estudo exalta a importância do mapeamento geológico e da análise mineral para estabelecer as relações entre as estruturas geológicas e a sismicidade em uma determinada área.

Palavras-chave: granito Meruoca, falha Riacho Fundo, estudos de sismicidade, Lineamento Transbrasiliano.

\section{REFERENCES}

Almeida FFM, Hasui Y, BRITO NeVES BB AND FUCK RA. 1981. Brazilian structural provinces: an introduction. Earth Sci Rev 17: 20-34.
ARChanjo CJ, LAUNEAU P, HOLLANDA MHBM, MACEDO JW AND PAND LIU D. 2009. Scattering of magnetic fabrics in the Cambrian alkaline granite of Meruoca (Ceará State, northeastern Brazil). Int J Earth Sci 98: 1793-1807.

ASSUMPÇÃO M. 1992. The regional intraplate stress field in South America. J Geophys Res 97(B8): 11889-11903.

BEZERrA FHR, DO NASCIMENTO AF, FERrEIRA JM, Nogueira FC, Fuck RA, Brito NeVEs BB AND SouzA MOL. 2011. Review of active faults in the Borborema Province, Intraplate South America - Integration of seismological and paleoseismological data. Tectonophys 510: 269-290.

BEZERRA FHR, TAKEYA MK, SOUSA MOL AND DO NASCIMENTO AF. 2007. Coseismic reactivation of the Samambaia fault, Brazil. Tectonophys 430: 27-39.

Bizzi LA, SchobBenhaus C, VidotTi RM AND GonÇALVES JH. 2003. Geologia, tectônica e Recursos Minerais do Brasil. Brasília: CPRM, 692 p.

Brito NeVes BB, Santos EJ And VAn Schmus WR. 2000. The tectonic History of the Borborema Province. In: Cordani UG et al. (Eds), Tectonic Evolution of South America, Rio de Janeiro: $31^{\text {st }}$ International Geological Congress, p. 151-182.

CPRM - Serviço Geológico do Brasil. 2003. Mapa Geológico do Estado do Ceará, Fortaleza-CE.

FERREIRA JM AND ASSUMPÇÃo M. 1983. Sismicidade do Nordeste do Brasil. Rev Bras Geofís 1: 67-88.

FERrEIRA JM, BEZERrA FHR, SOUSA MOL, NASCIMENTO AF AND FRANÇA GSLA. 2008. The role of Precambrian mylonitic belts and present-day stress field in the coseismic reactivation of the Pernambuco lineament, Brazil. Tectonophys 456: 111-126.

FERREIRA JM, OLIVEIRA RT, TAKEYA MK AND ASSUMPÇÃO M. 1998. Superposition of local and regional stresses in NE Brazil: evidence from local mechanisms around the Potiguar marginal basin, Geophys J Int 134: 341-355.

GOMES JRC ET AL. 1981. Geologia. In: PROJETO RADAMBRASIL. Folhas SB. 24/25 Jaguaríbe e Natal; geologia, geomorfologia, pedologia, vegetação e uso potencial da terra. Rio de Janeiro: MME/Secretaria Geral. p. 27-300.

LOPES AEV, AsSUMPÇÃo M, Do NASCIMENTO AF, FERREIRA JM, Menezes EAS AND BARBosa JR. 2010. Intraplate earthquake swarm in Belo Jardim, NE Brazil: reactivation of a major Neoproterozoic shear zone (Pernambuco Lineament). Geophys J Int 180: 1303-1312.

OLIVEIRADC. 2000. Stratigraphic interplays between igneous and sedimentary events in the early palaeozoic Jaibaras trough (Northeast Brazil). Rev Bras Geociênc 30(3):427-431.

OLIVEIRA DC AND MOHRIAK W. 2003. Jaibaras trough: an important element in the early tectonic evolution of the Parnaíba interior sag basin, Northern Brazil. Mar Petrol Geol 20: 351-383.

OLIVEIRA PHS, FERREIRA JM, DO NASCIMENTO AF, BEZERRA FHR, SOARES JE AND FUCK RA. 2010. Study of the Sobral area seismicity-CE, NE Brazil in 2008. Proceedings of Geophysics Brazilian Symposium. Brasília, 2010. 
Parente CV, Botelho NF, SAntos RV, Garcia MGM, Oliveira CG AND Verissimo CUV. 2011. Contexto Geológico, Tipológico e Geoquímico Isotópico das Brechas Hidrotermalizadas de Ferro e Cobre tipo IOCG, associadas à Bacia Eo-Paleozóica Jaibaras, da Província Borborema, Brasil. In: Frantz JC, Marques J and Jost H (Eds), Contribuições à Metalogenia do Brasil, Porto Alegre: UFRGS, v.1, p. 1-225.

Pedrosa JR NC, VidotTi RM AND FUCK RA. 2011. Interpretation of airborne geophysical data from the structural framework of Jaibaras Rift, Ceará, Brasil. Proceedings of $12^{\text {th }}$ International Congress of the Brazilian Geophysical Society, Rio de Janeiro, 2011.

SANDIFORM M AND EGHOLM DL. 2008. Enhanced intraplate seismicity along continental margins: Some causes and consequences. Tectonophys 457: 197-208.

SAntos TJS, Fetter AH AND NogueIRA Neto JA. 2008. Correlation of the west margin of the TransbrasilianoKandi Lineament in the Borborema Province (NE Brazil) and Pharusian Belt (NWAfrica). In: Pankhurst RJ, Trouw RAJ, BritoNeves BB and de Wit MJ (Eds.), West Gondwana: Pre-Cenozoic Correlations Across the South Atlantic Region. Geological Society, London. Special Publications 294: 101-119.
SCHOLZ CH. 1998. Earthquakes and friction laws. Nature 391: 37-42.

SiAL AN, FIGUEIREDO MCH AND LONG LE. 1981. Rare-earth element geochemistry of the Meruoca and Mucambo Plutons, Ceará, Northeast Brazil. Chem Geol 31: 271-283.

Souza ZS, VASCONCElos PM DE P, NASCIMENTO MAL, Silveira FV, PAIVA HS, Dias LGS, THIED D AND CARMO IO. 2003. 40Ar/39Ar geochronology of Mesozoic and Cenozoic magmatism in NE Brazil. Proceedings of IV South American Symposium on Isotope Geology, 2003, Salvador. Short Papers. Salvador: Companhia Baiana de Pesquisa Mineral, 2003. v. 2, p. 691-694.

SYKES LR. 1978. Intraplate seismicity, reactivation of preexisting zones of weakness, alkaline magmatism, and other tectonism postdating continental fragmentation, Rev Geophys Space Phys 16: 621-688. 
